Article

\title{
Investigating the Impact of Stimulus Equivalence on Children's Food Choice and Preference
}

\author{
Silvana Lopes dos Santos* \\ Orcid.org/0000-0001-6627-888X \\ Júlio César Coelho de Rose \\ Orcid.org/0000-0001-9122-8948
}

Universidade Federal de São Carlos, Departamento de Psicologia, São Carlos, SP, Brasil

\begin{abstract}
This study investigated the influence of character on food's choices. Eleven preschool children were trained to form two equivalent stimulus classes, each comprising one a cartoon character, a geometric shape, and an abstract symbol. One class had a liked character and the other a disliked character. Three preference tests were conducted where the children had to choose between two identical packages with samples of the same snack, differing only by the label. In Test 1 the labels were symbols of the same class as the liked and disliked characters; in Test 2 the choice was between the symbol of the same class as the disliked character and a new symbol; and in Test 3 children chose between the symbol of the equivalence class with the liked character and the logo of a known brand. Most children chose first, and reported to like more, the snack labeled with the symbol of the same class as the liked character. They also chose, and reported to like more, the snack labeled with a new stimulus over the symbol of the same class as the disliked character. These results confirmed that stimulus equivalence is a useful paradigm to investigate formation of preference for brands.
\end{abstract}

Keywords: Stimulus equivalence, transfer of function, food choice and preference, brand, cartoon character.

\section{Investigando o Impacto da Equivalência de Estímulos na Escolha e Preferência de Alimentos por Crianças}

\section{Resumo}

Esta pesquisa investigou a influência de personagens em escolhas alimentares. Doze crianças pré-escolares formaram inicialmente duas classes de estímulos equivalentes, cada uma contendo um personagem, uma forma geométrica e um símbolo abstrato. Uma das classes continha um personagem de que a criança gostava e a outra de que a criança não gostava. Três testes de escolha alimentar foram conduzidos nos quais o participante deveria escolher entre duas embalagens idênticas com o mesmo alimento,

* Mailing address: Universidade Federal de São Carlos, Departamento de Psicologia, Rodovia Washington Luis, km 235, C. P.: 676, São Carlos, SP, Brasil 13565-905. E-mail: silvana@ufscar.br and juliocderose@ yahoo.com.br

This research was part of the scientific program of Instituto Nacional de Ciência e Tecnologia sobre Comportamento, Cognição e Ensino (Deisy G. de Souza, chairperson), with support from the National Research Council (CNPq, Grant \# 573972/2008-7) and the São Paulo Research Foundation (FAPESP, Grant \# 2008/57705-8). Julio C. de Rose was supported a Research Productivity Grant from CNPq. We thank Deisy de Souza for her support and encouragement of this research. Special thanks to Micah Amd for his careful revision of the English writing of this manuscript. 
diferindo somente o rótulo. No Teste 1, os rótulos continham os símbolos da classe do personagem atrativo e não atrativo; No Teste 2, a escolha era entre o símbolo da classe do personagem não atrativo e um símbolo novo; e no Teste 3 a escolha era entre o símbolo da classe do personagem atrativo e o logo de uma marca conhecida. A maioria das crianças escolheu e demonstrou preferência pelo alimento com o símbolo equivalente ao personagem de que gostava. Também escolheram e disseram gostar mais do alimento com o símbolo novo no rótulo ao invés do que continha o símbolo equivalente ao personagem não atrativo. Os resultados apontam a equivalência de estímulos como uma abordagem útil para investigar a formação de preferência por marcas.

Palavras-chave: Equivalência de estímulos, transferência de função, escolhas e preferência alimentares, marca, personagem.

\section{Investigando el Impacto de la Equivalencia de Estímulos en la Elección y Preferencia de Alimentos por Niños}

\section{Resumen}

Este estudio investigó la influencia de los personajes en la elección de alimentos. 12 niños preescolares formaran dos clases de estímulos equivalentes, contiendo a un personaje infantil, una forma geométrica, y a un símbolo abstracto. Una clase tenía un personaje que le gustaba al niño y la otra un personaje que no le gustaba. Tres testes de preferencia fueron conducidos, en los que los niños tenían que escoger entre dos pedazos de la misma galleta, diferenciándose sólo por la etiqueta en el recipiente. En el Test 1, las etiquetas eran símbolos equivalentes al personaje que favorito y al que no le gustaba; en el Test 2, la elección fue entre el símbolo equivalente al personaje que no le gustaba y un símbolo nuevo; y en el Test 3 , nos niños escogían entre el símbolo equivalente al personaje favorito y el logotipo de una marca conocida. La mayoría de los niños escogió primero, y prefirieron, la galleta etiquetada con el símbolo equivalente al personaje favorito. También escogieron, y prefirieron, la galleta etiquetada con el estímulo nuevo que con el símbolo equivalente al personaje que no les gustaba. Estos resultados confirmaron que la equivalencia de estímulos es un paradigma útil para investigar la formación de preferencia por las marcas.

Palabras clave: Equivalencia de estímulos, transferencia de función, elección y preferencia de alimentos, marcas, personaje de dibujos animados.

The influence of food marketing on children's food choices and preference has been subject of much discussion recently (for a review, see Cairns, Angus, Hastings, \& Caraher, 2013). This rising interest is mostly due to increasing child obesity throughout the world, and health problems this may bring in adult life, such as hypertension, cardiovascular diseases, chronic respiratory diseases and diabetes. Being overweight during childhood and adolescence brings an increased risk of adult obesity. Data from the World Health Organization (WHO, 2015 ) indicate that in 2013, the number of overweight children with less than four years of age was estimated to be 42 million.
Evidence shows that television advertising influences children's food preferences and consumption patterns. The exposure to advertisement increases the intake of high caloric value (Borzekowski \& Robinson, 2001; Dalmeny, 2003; Halford, Boyland, Hughes, Oliveira, \& Dovye, 2007; Halford, Gillespie, Brown, Pontin, \& Dovey, 2004). Borzekowski and Robinson, for instance, concluded that only one or two exposures to an ad of 10 to 30 seconds in television could influence children's choices.

Other strategies of food marketing have been the development of attractive packaging for children (Mehta et al., 2012). Experiments show that children tend to prefer foods whose 
packages contain a familiar or favorite character or mascot (Elliott, Den Hoed, \& Conlon, 2013; Kotler, Schiffman, \& Hanson, 2012; Lapierre, Vaala, \& Linebarger, 2011; Roberto, Baik, Harris, \& Brownell, 2010). This strategy usually has better results for products of low nutritional value when compared, for instance, to fruits or vegetables (see Kraak \& Story, 2015, for a review).

Research has also demonstrated that children are capable of recognizing brand logos from a very young age, demonstrating particularly strong preferences for logos associated with mascots (Fischer, Schwartz, Richards, Goldstein, \& Rojas,1991; Macklin, 1986; Robinson, Borzekowski, Matheson, \& Kraemer, 2007; Valkenburg \& Buijzen, 2005). Robinson et al. (2007), for instance, verified that 3 to 5-year old children prefer foods and beverages that come in packaging displaying the McDonalds logo, when compared to similar products in unlabeled packages.

Classical conditioning was often proposed as an explanation of why previously neutral stimuli acquired emotional functions. For instance, advertisement often involves pairing brands (neutral) with positive stimuli, turning the brand into a conditioned stimulus that evokes positive emotions (Macklin, 1986; Stuart, Shimp, \& Engle, 1987; Sweldens, van Osselaer, \& Janiszewski, 2010). Also described as evaluative conditioning (EC), this process describes changes in the valence of a stimulus in accordance with the valence of another stimulus with which it had been paired (for reviews, see De Houwer, Thomas, \& Baeyens, 2001).

A behavior-analytic simulation of the effects of advertisement on children's preferences is possible with the stimulus equivalence paradigm (Barnes-Holmes, Keane, Barnes-Holmes, \& Smeets, 2000; Smeets \& Barnes-Holmes, 2003). This paradigm is a model that provides an account for emergent novel behavior following the establishment of stimulus relations (Barnes-Holmes, Barnes-Holmes, Smeets, \& Luciano, 2004; Bortoloti \& de Rose, 2009, 2012; Dougher, Augustsson, Markham, Greenway, \& Wulfert, 1994; Sidman, 1994; Sidman \& Tailby, 1982). Relations are typically established experimentally with a matching-to-sample (MTS) pro- cedure in which each of a series of trials displays a sample (e.g., A1, or A2, or An) along with two or more comparison stimuli (B1, B2, and Bn). Often a response to the sample is required to produce the presentation of the comparison stimuli, to increase the probability that the participant observes the sample. In simultaneous matching to sample (SMTS), a response to the sample is followed by the presentation of comparisons and both sample and comparisons remain on the screen until one of the comparisons is chosen. In delayed matching-to-sample (DMTS), a response to the sample produces the withdrawal of the sample and the comparison stimuli are displayed after a delay (Arntzen, 2012). Choices of comparison stimulus $\mathrm{Bn}$ are reinforced in the presence of sample An. This establishes a stimulus relation designated as $\mathrm{AB}$. A BC relation may be established in a likewise manner by reinforcing selection of comparison stimulus $\mathrm{Cn}$ in the presence of sample Bn. Stimulus equivalence is demonstrated when, after relations $\mathrm{AB}$ and $\mathrm{BC}$ are established by direct training, new relations emerge without direct training. These emergent/ derived relations attest symmetry (BA and $\mathrm{CB}$ ), transitivity (AC), and combined symmetry and transitivity (CA) of the trained relations (Sidman, 1994; Sidman \& Tailby, 1982).

Several studies have demonstrated that when a class of equivalent stimuli is established, functions acquired by one member of the class will transfer to the other members. In other words, equivalent stimuli substitute each other in the control of behavior (Barnes-Holmes et al., 2004; de Rose, McIlvane, Dube, Galpin, \& Stoddard, 1988; Dougher et al., 1994; Grey \& Barnes, 1996; Wulfert \& Hayes, 1988). Bortoloti and de Rose (2009), for example, trained college students in matching-to-sample (MTS) relations that resulted in the formation of three classes of equivalent stimuli, each comprising one meaningful stimulus and three or five abstract stimuli. The meaningful stimuli included pictures of faces with happy, neutral and angry expressions. The researchers reasoned that a transfer of functions would consequate the arbitrary stimuli acquiringe a meaning similar to that of the faces. Those authors used a seman- 
tic differential (Osgood, Suci, \& Tannenbaum, 1957) to assess meaning of the faces and the arbitrary stimuli. A control group which did not receive MTS training rated the faces and one arbitrary stimulus from each prospective class. Experimental groups were comprised of participants that showed equivalence class formation: they rated only arbitrary stimuli, one from each class. As expected, ratings of the arbitrary stimuli from the experimental groups were similar to the ratings of the equivalent faces (which were made by the control group). This similarity was interpreted to indicate a transfer of meaning from the faces to the arbitrary equivalent stimuli. Bortoloti and de Rose found that transfer of meaning was stronger when training to promote equivalence class formation was conducted with DMTS than with SMTS. This result is consistent with other studies showing that DMTS training produces more reliable transfer of meaning effects than SMTS (Bortoloti \& de Rose, 2007, 2012; de Almeida \& de Rose, 2015).

Smeets and Barnes-Holmes (2003) investigated the influence of stimulus equivalence and transfer of function between cartoons character and abstracts symbols on children's preference for soft drinks. The MTS procedure established two classes of equivalent stimuli, one comprising $\mathrm{A} 1, \mathrm{~B} 1$, and $\mathrm{C} 1$, and the other comprising $\mathrm{A} 2$, B2, and $\mathrm{C} 2$. A1 was a picture of a cartoon character (Ernie), and A2 was a picture of a child crying. The other stimuli were arbitrary nonsense stimuli. Next, each child was presented with two samples of the same soft drink, one in a bottle labeled with stimulus C1 (equivalent to Ernie) and the other in a bottle labeled with stimulus $\mathrm{C} 2$ (equivalent to the crying child). Children were told that they would taste the contents of the two bottles and were asked which one they wanted to try first. After they tried the contents of both bottles, they were asked which one they preferred. The drink with the label equivalent to Ernie was preferred. This confirmed results of similar studies conducted with college students (Arntzen, Fagerstrom, \& Foxall, 2016; Barnes-Holmes et al., 2000). These studies demonstrated that abstracts symbols acquired the meaning of pictures (with presumed positive and negative valences) through stimulus equivalence and could influence the preference for drinks labeled with these symbols.

The stimulus equivalence paradigm indicates, therefore, that the presence of a favorite character on a food package is not necessary: a symbol equivalent to an attractive figure would suffice to enhance preference for a product. Previous research suggested that stimulus equivalence is a useful paradigm to a behavioral investigation of the formation and changes of attitudes (de Carvalho \& de Rose, 2014; Grey \& Barnes, 1996; Mizael, Santos, \& de Rose, 2016; Moxon, Keenan, \& Hine, 1993; Watt, Keenan, Barnes, \& Cairns, 1991; see also de Almeida \& de Rose, 2015). To illustrate, Grey and Barnes (1996, Experiment 1) trained college students to form three classes comprising nonsense syllables (A1B1C1, A2B2C2 and A3B3C3). Each participant was then presented two movies: one with religious scenes and the other with sexual content. Each video had the cover labeled with the nonsense syllables B1 and B2 of the MTS procedure. After watching the movies, participants were required to sort these two movies and four unseen movies into two categories: good and bad. The unseen movies had their covers labeled with the other nonsense syllables of the two classes (e.g. A1, C1, A2, C2). The participants evaluated the movies according to the equivalence classes to which their labels belonged. If the movie labeled with B1 was considered bad, the movies labeled with $\mathrm{A} 1$ and $\mathrm{C} 1$ were also considered bad, despite the fact that the participant had not seen them. These results show that individuals may change their evaluations and preferences for a stimulus (i.e., their attitudes) in the absence of direct experience with this stimulus (object or event), based only on experiences with equivalent stimuli.

The present study was conducted considering the importance of these questions to strengthen the area of stimuli equivalence and the social relevance that involves the influence of marketing on children food preferences. We aimed to replicate and extend the findings of Smeets and Barnes-Holmes (2003). In this study, when children were asked which drink they preferred, they 
often did not express a preference (saying, for instance, that the drinks tasted the same) and had to be prompted by the experimenter to report a preference. In the present study, parametric changes were made in an attempt to increase the transfer of meaning to the abstract labels. The procedure was conducted using a DMTS training with a delay $(1 \mathrm{sec})$ between sample offset and onset of comparisons. Two 3-member equivalence classes were established, each comprising a cartoon character and two arbitrary stimuli. One of the classes had a liked cartoon character and the other had a disliked cartoon character chosen by the children. Soft drinks were replaced by other industrialized foods, already familiar to the children. Further preference tests were added, including novel symbols and logos of brands familiar to the children.

\section{Method}

\section{Participants}

Participants were 12 preschool children (nine boys and three girls), with ages ranging from 5 to 6 years. The children were recruited through school contacts following the receipt of written consent from the respective parents.
The parents were also required to complete a questionnaire regarding their children's food preferences and restrictions, knowledge about food brands, and cartoons characters they liked or disliked. Our selection criterion involved recruiting children who feel within a 5-6 year age range. The Human Research Ethics Committee of the Federal University of São Carlos approved the research reported here (CAAE no. 09966612.1.0000.5504).

\section{Equipment, Setting, and Materials}

Sessions were conducted individually in a room of the pre-school attended by the participants. Children sat facing the computer with the researcher sitting beside them. A notebook with the MESTRE software (Elias \& Goyos, 2010) presented the stimuli and recorded participants' responses in matching-to-sample trials. Sessions were recorded with a digital camera.

Figure 1 shows the stimuli used in the experiment. Stimuli A1 and A2 were, respectively, a liked and a disliked cartoon character as indicated earlier by each participant (therefore, the A1/A2 stimuli were individually tailored for each individual). Stimuli from set B constituted of a square (B1) and a triangle (B2), whereas set $\mathrm{C}$ comprised of abstract pictures.
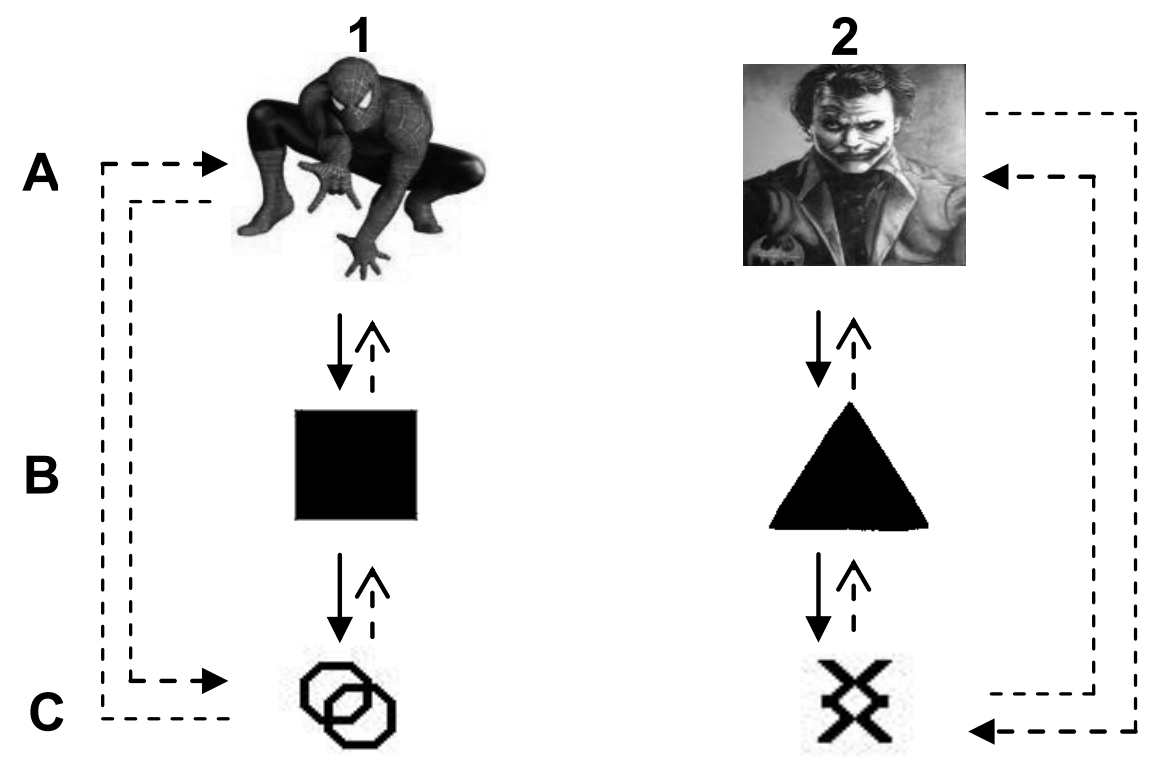

Figure 1. Example of schematic representation of the trained (solid arrows) and tested (broken arrows) relations. 
Transparent plastic containers with small food samples were used to test for preferences. Foods used with each child were chosen based on their preferences and restrictions, as reported by their parents and children themselves. Choices for most of them were crackers (Test 1), fermented milk or soy-based fruit juice (Test 2 ) and chocolate (Test 3 ).

\section{Procedure}

The general procedure consisted of three phases: pre training, relational training and testing, and food choice and preference tests. The children participated in five experimental sessions over the course of two weeks. Sessions lasted no longer than 10 minutes each.

Phase 1 - Choice of Stimuli and MTS PreTraining.

The first session was conducted to select stimuli A1 (a liked character) and A2 (a disliked character) for each child. Knowledge of food brands was also verified.

To choose the most liked character, colorpictures of six characters (reported by parents in the questionnaire, together with other characters that children usually like) were printed $(6 \mathrm{~cm} \mathrm{x}$ $6 \mathrm{~cm}$ ) and displayed horizontally on the desk. Participants were asked "Which of these characters do you like most?" The character the participant picked was chosen as A1 for that child. To assure that the picked character was the most preferred by the child, s/he was asked whether there was another character, not displayed in the choice pool, which s/he liked more. A similar procedure was used for the choice of the disliked character.

To test brand recognition, black-and-white logos of food brands were printed $(6 \mathrm{~cm} \mathrm{x} 6 \mathrm{~cm})$ and displayed to the participant one at a time. For each logo, the participant was asked: "Do you know what this is?" The brand that $\mathrm{s} /$ he demonstrated to recognize (saying the brand's name or the product) was chosen for the experiment.

A delayed matching-to-sample pre-training was conducted to familiarize the participant with the method. It comprised eight identity-matching trials (in which the task was to choose a compar- ison stimulus that was identical to the sample) with familiar stimuli (ball, lamp, animals, etc.). They received the instruction:

We are now going to play a game. A picture will appear on the center of the screen. When you click on this picture, two other pictures will appear below. You will score points if you click on one of them and not on the other.

The researcher remained beside the child and reinforced her correct responses with verbal praise ("very good", "you got it").

When the child responded correctly, an animation of a little pig receiving a coin was presented on the computer, and a marble was placed on a transparent container next to the computer. If the response was incorrect, the computer screen went blank for 3 seconds. This block of trials was repeated until the child responded correctly across all eight trials.

Phase 2 - Relational Training and Testing.

This phase occurred in sessions 2 through 4. The training protocol was simple-to-complex (STC, cf.: Adams, Fields, \& Vehave, 1993). In this protocol, training started with the $\mathrm{AB}$ relation, followed by a test of BA symmetry. After participants demonstrated the emergence of $\mathrm{BA}$ symmetry, the $\mathrm{BC}$ relation was taught, followed by the CB symmetry test. Transitivity (AC) and combined symmetry and transitivity (CA) were then tested. The conditional discrimination training of the $\mathrm{AB}$ relation was conducted in Session 2. The first training block consisted of 12 trials (six A1B1 and six A2B2) in which samples were either $\mathrm{A} 1$ or $\mathrm{A} 2$, and both $\mathrm{B} 1$ and $\mathrm{B} 2$ were presented with equal frequency on the left and the right positions. Participants received the following instruction:

We are now going to play a game like the one we played the other day. A picture will appear on the center of the screen, we will click on it and two other pictures will appear below. There is one of them for which, if you click on it, the little pig will appear on the screen, you will score points, and I will place a marble on this container here. Pay attention because in the initial two trials, a 
finger pointing to the picture will appear on the screen. You should click on this picture to score points and you will be able to trade your marbles for a sticker at the end.

The child was required to click on the sample, to increase the likelihood that $\mathrm{s} / \mathrm{he}$ observed it. This observing response to the sample was followed by the offset of the sample and, $1 \mathrm{sec}$ later, the onset of the two comparison stimuli, B1 and $\mathrm{B} 2$, in randomized positions of the screen. $\mathrm{A}$ click on the correct alternative (B1 for sample $\mathrm{A} 1$, and $\mathrm{B} 2$ for sample A2) produced the consequences. The block was repeated until the child performed no more than one incorrect response. The prompts for the two initial trials occurred only in the first presentation of the block, and then the second block started with ten trials (five A1B1 and five A2B2).

After criterion was attained, a symmetry test with blocks of eight trials (four B1A1 and four B2A2) was conducted to verify the symmetrical BA relation. Children received the instruction: "Now the pig will no longer appear and I will not tell you if you got it right or wrong. Pay attention and do your best." Criterion to advance to the next phase with no more than one incorrect response. If this criterion was not attained within three test blocks, then the participant would be dismissed, but this did not occur for any participant.

The same procedure was used in Session 3 to train the $\mathrm{BC}$ relation and test for symmetry (CB). Session 4 conducted tests to verify transitivity (AC) and combined transitivity and sym- metry $(\mathrm{CA})$ of the trained relations. The AC relation was tested first, followed by tests for CA, using the same procedure as earlier symmetry tests.

Phase 3-Food Choice and Preference Test.

Session 5 was conducted to verify the transfer of function. This session occurred between two and four days after Session 4. The child was told s/he would have snacks and was asked to sit on the chair close to the desk. The experimenter stayed behind the child so as to avoid providing non-intentional visual cues. The experimenter placed two identical transparent containers containing the same snack over the desk. The containers differed only by the label on the front (see Figure 2). The participant received the instruction: "Here are two [name of the snack]. You can eat/drink both. Which one do you want to eat/ drink first?" The participant chose the snack and ate or drank it. Then, the child was asked to eat or drink the snack from the other container too, and then the experimenter asked which one s/he liked most. If the child did not demonstrate any preference (saying, for instance, that the snacks were the same), s/he was asked "Are you sure? You should have liked one more." Three tests were conducted, each with a different snack. In the first test, one of the containers was labeled with $\mathrm{C} 1$ and the other with $\mathrm{C} 2$. In the second test, one of the containers was labeled with $\mathrm{C} 2$ and the other with a novel symbol (NS). In the third test, one of the containers was labeled with $\mathrm{C} 1$ and the other with the logo of a known brand (KB).

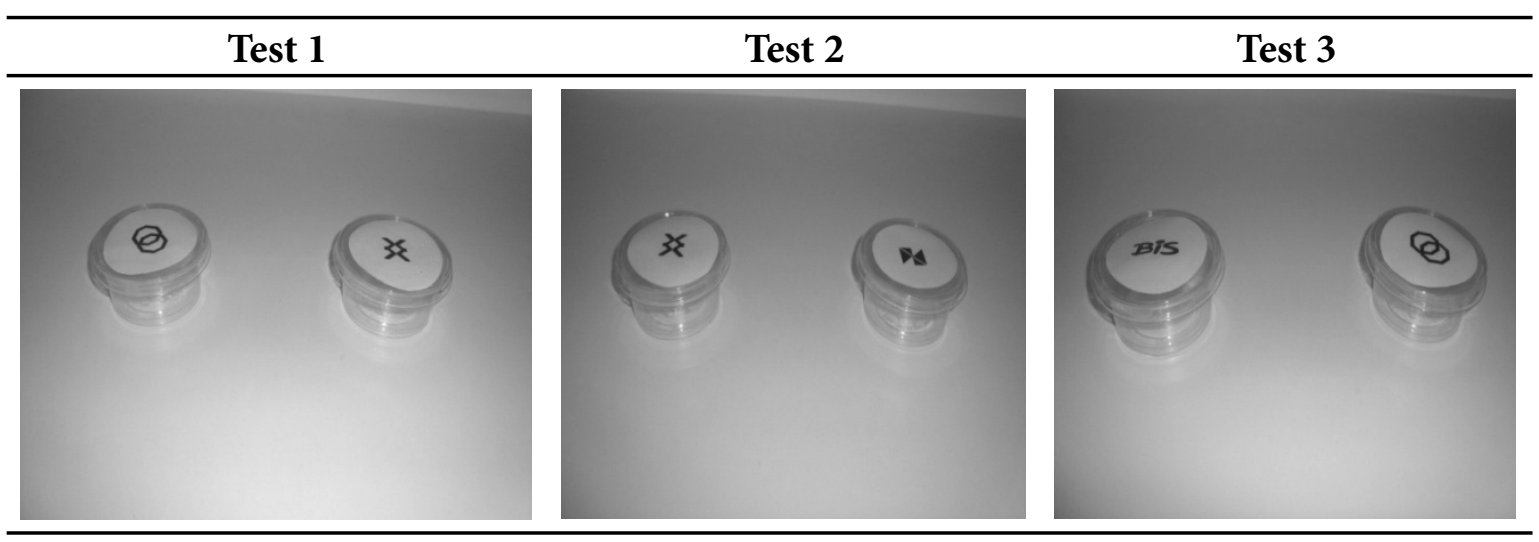

Figure 2. Illustration of container and labels used on the three choice and preference tests. 


\section{Results}

Table 1 presents results of matching-tosample training and equivalence tests. All participants except $\mathrm{P} 1$ reached criterion during all training and testing phases. These participants required $7-12$ blocks in total $(M=8)$ to meet criteria (range: $54-83$ trials; $M=61$ ). $\mathrm{P} 1$ did not attain criterion in six blocks of $\mathrm{AB}$ training and did not advance to subsequent phases. A total of ten participants $(83 \%)$ passed the relational training and testing phases demonstrating that the procedure was effective for establishing equivalence relations. P5, P6 and P7 required two blocks of the combined symmetry/transitivity test (CA) and P2 did not attain criterion in this test.

Table 1

Age, Gender, Number of Trial Blocks in Each Phase, and Results of Equivalence Tests for Each Participant

\begin{tabular}{cccccccccc}
\hline P\# & Sex & Age & AB & BA & BC & CB & AC & CA & Result \\
\hline P1 & F & 5,4 & 6 & --- & --- & --- & $-\cdots$ & --- & --- \\
P2 & M & 5,7 & 3 & 2 & 1 & 1 & 1 & 1 & Fail \\
P3 & M & 5,7 & 4 & 2 & 1 & 3 & 1 & 1 & Pass \\
P4 & F & 5,6 & 1 & 1 & 1 & 1 & 1 & 1 & Pass \\
P5 & M & 5,8 & 1 & 1 & 1 & 1 & 1 & 2 & Pass \\
P6 & M & 5,9 & 1 & 2 & 1 & 2 & 1 & 2 & Pass \\
P7 & M & 5,9 & 3 & 2 & 1 & 1 & 1 & 1 & Pass \\
P8 & F & 5,8 & 3 & 1 & 1 & 2 & 1 & 1 & Pass \\
P9 & M & 5,11 & 1 & 1 & 1 & 1 & 1 & 2 & Pass \\
P10 & M & 5,3 & 2 & 1 & 1 & 1 & 2 & 1 & Pass \\
P11 & M & 5,2 & 2 & 1 & 3 & 1 & 1 & 1 & Pass \\
P12 & M & 5,9 & 2 & 1 & 1 & 1 & 1 & 1 & Pass \\
\hline
\end{tabular}

Table 2 presents results from transfer of function tests conducted with participants who had demonstrated equivalence. In Test 1 , in which children had to choose between containers labeled with $\mathrm{C} 1$ (equivalent to the liked character) and $\mathrm{C} 2$ (equivalent to the disliked character), the difference in the percentage of choices of C1 $(90 \%)$ and $\mathrm{C} 2(10 \%)$ was statistically significant, $\chi^{2}(1)=6,400 ; p<.011$. When children were asked which one they liked more, $80 \%$ said it was the snack labeled with $\mathrm{C} 1, \chi^{2}$ $(1)=6,300 ; p<.058$. Considering the relation between choice and preference, a total of $70 \%$ of the children chose the snack labeled with $\mathrm{C} 1$ and reported they liked it more, $\chi^{2}(1)=1,600$; $p<.206$.

In Test 2, between snacks labeled with $\mathrm{C} 2$ (equivalent to the disliked character) and NS (a novel symbol), $90 \%$ chose to try first the snack labeled with NS, $\chi^{2}(1)=6,400 ; p<.011$, and $80 \%$ reported to like more the snack labeled with NS, $\chi^{2}(1)=6,300 ; p<.058$. Two participants reported to like more the snack labeled with $\mathrm{C} 2$ and a third said the snacks were equal. When 
Table 2

Results of the Transfer of Functions Tests

\begin{tabular}{|c|c|c|c|c|c|c|}
\hline \multirow[t]{2}{*}{ P\# } & \multicolumn{2}{|c|}{$\begin{array}{c}\text { Test } 1 \\
\text { C1 vs C2 }\end{array}$} & \multicolumn{2}{|c|}{$\begin{array}{c}\text { Test } 2 \\
\text { C2vs NS }\end{array}$} & \multicolumn{2}{|c|}{$\begin{array}{c}\text { Test } 3 \\
\text { C1vs KB }\end{array}$} \\
\hline & $\mathrm{C}$ & $\mathrm{P}$ & C & $\mathrm{P}$ & $\mathrm{C}$ & $\mathrm{P}$ \\
\hline P3 & $\mathrm{C} 1$ & $\mathrm{C} 1$ & NS & NS & $\mathrm{KB}$ & $\mathrm{KB}$ \\
\hline $\mathrm{P} 4$ & $\mathrm{C} 1$ & $\mathrm{C} 1$ & NS & NS & $\mathrm{KB}$ & $\mathrm{C} 1$ \\
\hline P5 & $\mathrm{C} 1$ & C2 & NS & NS & $\mathrm{KB}$ & $\mathrm{KB}$ \\
\hline P6 & $\mathrm{C} 1$ & $\mathrm{C} 2$ & $\mathrm{C} 2$ & $\mathrm{C} 2$ & $\mathrm{C} 1$ & $\mathrm{NP} / \mathrm{C} 1$ \\
\hline P7 & $\mathrm{C} 1$ & $\mathrm{C} 1$ & NS & NS & $\mathrm{KB}$ & $\mathrm{C} 1$ \\
\hline P8 & $\mathrm{C} 1$ & $\mathrm{C} 1$ & NS & NP/NS & $\mathrm{KB}$ & KB \\
\hline P9 & $\mathrm{C} 1$ & $\mathrm{C} 1$ & NS & C2 & $\mathrm{KB}$ & $\mathrm{C} 1$ \\
\hline P10 & $\mathrm{C} 2$ & $\mathrm{C} 1$ & NS & NS & $\mathrm{KB}$ & $\mathrm{KB}$ \\
\hline P11 & $\mathrm{C} 1$ & $\mathrm{C} 1$ & NS & NS & $\mathrm{C} 1$ & $\mathrm{C} 1$ \\
\hline P12 & $\mathrm{C} 1$ & $\mathrm{C} 1$ & NS & NS & $\mathrm{C} 1$ & $\mathrm{~KB}$ \\
\hline
\end{tabular}

Note.C: Chose, P: preference, NS: New Symbol, KB: known brand, NP: No preference.

prompted to express a preference, this child said the snack labeled with NS tasted better. Therefore, a total of $80 \%$ both chose the snack labeled with NS and reported they liked it more, $\chi^{2}(1)=$ 3,$600 ; p<.058$.

In Test $3,70 \%$ of the children chose to taste first the snack labeled with the logo of the known brand, $\chi^{2}(1)=1,600 ; p<.206$, but $50 \%$ reported to like more the snack with the same logo. Considering the relation choice and preference, only $40 \%$ chose the snack labeled with $\mathrm{KB}$ and reported they liked it more. These differences were not statistically significant.

\section{Discussion}

The present study confirms the earlier results of Smeets and Barnes-Holmes (2003), where children were observed to initially select a snack labeled with a symbol equivalent to a liked character and report preferring it over an identical snack labeled with a symbol equivalent to a disliked character. The previous research conducted only one test, similar to Test 1 of the present study, whereas we conducted two additional tests. Test 2 showed that a new stimulus
(NS) was preferred in relation to the symbol of the unattractive character $(\mathrm{C} 2)$. Results of the third test, comparing preference for the symbol of the attractive character (C1) and the logo of a known brand, were inconclusive.

Smeets and Barnes-Holmes (2003) noted that their results could be considered "weak" because $46 \%$ of the children initially reported no preference between the drinks and needed additional prompts to indicate a preference. Results of the present study appear much stronger in this regard given that no child required prompts in the first test ( $\mathrm{C} 1$ vs. $\mathrm{C} 2$ ), with only one child requiring prompts in the second and third tests. Many recent studies have shown that several training parameters may enhance transfer of functions. One of these parameters is training with DMTS (Bortoloti \& de Rose, 2007, 2009, 2011, 2012). Therefore, the use of DMTS in the present study may have strengthened transfer of functions, as compared to SMTS used in the study of Smeets and Barnes-Holmes. Another manipulation that may have enhanced function transfer in the present study is the use of a simple-to-complex protocol (see, for instance, the study by Mizael, de Almeida, Silveira, \& de Rose, 2016). Also, 
Smeets and Barnes-Holmes acknowledged that effects in their study may have been weakened because they did not conduct preference assessments for stimuli before the beginning of the study. In the present study, preference tests were conducted to select a preferred and a disliked character, which varied for each child according to the results of these tests. It is likely, therefore, that training parameters of the present study favored function transfer relative to the work reported by Smeets and Branes-Holmes. This enhanced transfer of functions is inferred from results of the preference tests across which the majority of children required no additional prompts for reporting preferences, with the exception of one child. Future researchers could consider estimating the magnitude of function transfer by incorporating explicit ratings scales, such as the Self-Assessment Manikin (Bradley \& Lang, 1994).

The tests described here suggest that both positive and negative functions of the cartoon characters had transferred to the equivalent symbols $\mathrm{C} 1$ and $\mathrm{C} 2$, respectively. Although this seems to be the more likely explanation, transfer of both positive and negative functions is not required to explain the results. Results of Test 1 could result from transfer only of the positive functions or only of the negative functions. Thus, preference for $\mathrm{C} 1$ in the first test would be expected if $\mathrm{C} 1$ were positive and $\mathrm{C} 2$ negative, but this would not be required: if $\mathrm{C} 1$ were positive and $\mathrm{C} 2$ neutral, or if $\mathrm{C} 1$ were neutral and $\mathrm{C} 2$ negative, we would also expect choices of $\mathrm{C} 1$. This same reasoning would apply to the study by Smeets and Barnes-Holmes (2003). Results of Test 2 might be produced by transfer of the negative functions to $\mathrm{C} 2$, or by a preference for novel stimuli. Children in this age range can exhibit preferences for novel stimuli over familiar ones (Grisante, de Rose, \& McIIvane, 2014; Valenti, 1985). We suggest that further studies should also test for preferences between symbols related to a liked character alongside novel symbols. There is some evidence to suggest increased transfer effects for stimuli with positive valences, such as happy faces, when contrasted with stimuli with negative valences, such as angry faces (Bortoloti, Rodrigues, Cortez, Pimentel, \& de Rose, 2013; Silveira et al., 2015).

The choice of the familiar brand in Test 3 , rather than the symbol of the attractive character, is consistent with studies demonstrating that very young children are capable of recognizing logos and demonstrating preferences for them (Fischer et al., 1991; Robinson et al., 2007; Valkenburg \& Buijzen, 2005). It may have been the case that the amount of training was not enough for the symbol related to the attractive character $(\mathrm{C} 1)$ to prevail against a known brand. However, $50 \%$ of the children reported having liked more the food labeled with $\mathrm{C} 1$. Perhaps choice and preference for the know brand would be more consistent if the logo was printed in color, rather than in black and white. While the colors were initially removed in order to control for potential visual confounds, doing so may have interfered with accurately identifying a brand, given the importance of color in pictures for the age range of our present cohort (Macklin, 1986). A final possible limitation is that the pre-tests did not assess evaluation of brands, only the recognition of them, hence the valences for the brands remain unknown.

Our results demonstrate how the establishment of equivalence relations between symbols and characters can influence both choice and preference. The present study established equivalence relations between brands and characters through matching-to-sample relations with geometric shapes. Brands and cartoon characters never appeared together during training trials. This contradicts presentations in advertisements, where brands and appetitive stimuli are directly paired. It is unlikely, however, that classical conditioning in a traditional sense could account for the present results, as well as for those of Smeets and Barnes-Holmes (2003). One might argue that during $\mathrm{AB}$ matching to sample training, the attractive character was paired with stimulus B1, which was then paired with the label $\mathrm{C} 1$. Note, however, that this would be backward conditioning, with the US presented first, which is unlikely to yield classical conditioning effects. It would, 
moreover, be second-order, or even third-order classical conditioning, which would be even more unlikely (see Smeets \& Barnes-Holmes, 2003). The delayed matching procedure used in the present study would make classical conditioning even more unlikely, because the putative US would disappear before the CS presentation.

Research on stimulus equivalence and transfer of functions has provided evidence that formation of equivalence classes establishes equivalent stimuli as substitutes for each other. After an equivalence class has been established, a function given to one member of a class may transfer to other members of that class, including emotional responses (e.g., Amd, BarnesHolmes, \& Ivanoff, 2013; Bortoloti \& de Rose, 2009, 2012; de Almeida \& de Rose, 2015; de Rose et al., 1988; Dougher et al., 1994; Wulfert \& Hayes, 1988). Research on fear and anxiety has indicated that fear evoked by a member of a class of equivalent stimuli transfer to the other members (e.g., Bennett, Meulders, Baeyens, \& Vlaeyen, 2015; Dymond, Dunsmoor, Vervliet, Roche, \& Hermans, 2015; Guinther \& Dougher, 2010), an effect some of these authors called symbolic, or category-based generalization (see Dymond et al., 2015). The studies of BarnesHolmes et al. (2000) and Smeets and BarnesHolmes (2003) as well as the present study indicate that the same effect can account for the acquisition of positive emotional functions by brands related to attractive characters.

These results support the conclusion that advertisements may influence children's choices and preferences by establishing the relation between brands and characters or mascots. To the extent that such advertisement is done mostly for highly caloric products of low nutritional value, this may contribute to elevate rates of child obesity, alongside other potential health problems. Our results suggest that it is possible to manipulate children's attitudes toward healthy foods by establishing equivalence relations between such foods (e.g., fruits and vegetables) and preferred cartoon characters. A preliminary investigation by Straatmann, Almeida, and de Rose (2014) suggested this possibility by demonstrating alterations in adolescents' preference towards fictitious foods following the establishment of equivalence relations between the latter and socially positive symbols. It remains to be seen whether this effect would be observed with real (healthy) foods as well.

\section{References}

Adams, B. J., Fields, L., \& Verhave, T. (1993). Effects of test order on intersubject variability during equivalence class formation. The Psychological Record, 43, 133-152.

Amd, M., Barnes-Holmes, D., \& Ivanoff, J. (2013). A derived transfer of eliciting emotional functions using differences among electroencephalograms as a dependent measure. Journal of the Experimental Analysis of Behavior, 99, 318-334. doi:10.1002/jeab.19

Arntzen, E. (2012). Training and testing parameters in formation of stimulus equivalence: Methodological issues. European Journal of Behavior Analysis, 13(1), 123-135.

Arntzen, E., Fagerstrom, A., \& Foxall, G. (2016). Equivalence classes and preferences in consumer choices. In G. R. Foxall (Ed.), The Routledge Companion to Consumer Behavior Analysis ( $p p$. 65-77). New York: Routledge.

Barnes-Holmes, D., Keane, J., Barnes-Holmes, Y., \& Smeets, P. M. (2000). A derived transfer of emotive functions as a means of establishing differential preferences for soft drinks. The Psychological Record, 50, 493-511.

Barnes-Holmes, Y., Barnes-Holmes, D., Smeets, P. M., \& Luciano, C. (2004). A derived transfer of mood functions through equivalence relations. The Psychological Record, 54, 95-104.

Bennett, M. P., Meulders, A., Baeyens, F., \& Vlaeyen, J. W. S. (2015). Words putting pain in motion: The generalization of pain-related fear within an artificial stimulus category. Frontiers in Psychology, 6, 520. doi:10.3389/fpsyg.2015.00520

Bortoloti, R., \& de Rose, J. C. (2007). Medida do grau de relacionamento entre estímulos equivalentes [Measuring the degree of relatedness between equivalent stimuli]. Psicologia: Reflexão e Crítica, 20(2), 250-256.

Bortoloti, R., \& de Rose, J. C. (2009). Assessment of the relatedness of equivalent stimuli through a semantic differential. The Psychological Record, 59, 534-590. 
Bortoloti, R., \& de Rose, J. C. (2011). Avaliação do efeito de dicasemântica e da indução de significado entre estímulos abstratos equivalentes [Assessment of the effects of semantic priming and induction of meaning between abstract equivalent stimuli]. Psicologia: Reflexão e Crítica, 24(2), 381-393.

Bortoloti, R., \& de Rose, J. C. (2012). Equivalent stimuli are more strongly related after training with delayed matching than after simultaneous matching: A study using the implicit relational assessment procedure (IRAP). The Psychological Record, 62(1), 41-54.

Bortoloti, R., Rodrigues, N. C., Cortez, M. D., Pimentel, N., \& de Rose, J. C. (2013). Overtraining increases the strength of equivalence relations. Psychology \& Neuroscience, 6, 357-364. doi:10.3922/j.psns.2013.3.13

Borzekowski, D. L., \& Robinson, T. N. (2001). The 30-second effect: An experiment revealing the impact of television commercials on food preferences of preschoolers. Journal American Diet Association, 101(1), 42-46.

Bradley, M., \& Lang. P. J. (1994). Measuring emotion: The Self-Assessment Manikin and the Semantic Differential. Journal of Behavior Therapy and Experimental Psychiatric, 25(1), 49-59.

Cairns, G., Angus, K., Hastings, G., \& Caraher, M. (2013). Systematic reviews of the evidence on the nature, extent and effects of food marketing to children. A retrospective summary. Appetite, 62, 209-215.

Dalmeny, K. (2003). Food marketing: The role of advertising in child health. Consumer Policy Review, 13(1), 2-7.

De Almeida, J. H., \& de Rose, J. C. (2015). Changing the meaningfulness of abstract stimuli by the reorganization of equivalence classes: Effects of delayed matching. The Psychological Record, 65, 451-461. doi:10.1007/s40732-015-0120-9.

De Carvalho, M. P., \& de Rose, J. C. (2014). Understanding racial attitudes through the stimulus equivalence paradigm. The Psychological Record, 64, 527-536. doi:10.1007/s40732-0140049-4

De Houwer, J., Thomas, S., \& Baeyens, F. (2001). Associative learning of likes and dislikes: A review of 25 years of research on human evaluative conditioning. Psychological Bulletin, 127, 853-869. doi:10.1037/0033-2909.127.6.853
De Rose, J. C., McIlvane, W. J., Dube, W. V., Galpin, V. C., \& Stoddard, L. T. (1988). Emergent simple discriminations established by indirect relations to differential consequences. Journal of the Experimental Analysis of Behavior, 50, 1-20. doi:10.1901/jeab.1988.50-1

Dougher, M. J., Augustson, E., Markham, M. R., Greenway, D. E., \& Wulfert, E. (1994). The transfer of respondent eliciting and extinction functions through stimulus equivalence classes. Journal of the Experimental Analysis of Behavior, 62(3), 331-351. doi:10.1901/jeab.1994.62-331

Dymond, S., Dunsmoor, J. E., Vervliet, B., Roche, B., \& Hermans, D. (2015). Fear generalization in humans: Systematic review and implications for anxiety disorder research. Behavior Therapy, 45, 561-582. doi.org/10.1016/j.beth.2014.10.001

Elias, N. C., \& Goyos, C. (2010). Mestre Libras no ensino de sinais: Tarefas informatizadas de escolha de acordo com o modelo e equivalência de estímulos [Mestre Libras for teaching signs: Computerized matching to sample tasks and stimulus equivalence]. In E. G. Mendes \& $\mathrm{M}$. A. Almeida (Eds.), Das Margens Ao Centro: Perspectivas para as Políticas e Práticas Educacionais no Contexto da Educação Especial Inclusiva [From the margins to the center: Perspectives for educational policies and practices in the contex of inclusive special education] (pp. 223-234). Araraquara, SP: Junqueira \& Marin.

Elliott, C. D., Den Hoed, R. C., \& Conlon, M. J. (2013). Food branding and young children's taste preferences: A reassessment. Canadian Journal of Public Health, 104(5), 364-368.

Fischer, P. M., Schwartz, M. P., Richards, J. W., Jr., Goldstein, A. O., \& Rojas, T. H. (1991). Brand logo recognition by children aged 3 to 6 years: Mickey Mouse and Old Joe the Camel. The Journal of de American Medical Association, 266(22), 3145-3148.

Grey, I. M., \& Barnes, D. (1996). Stimulus equivalence and attitudes. The Psychological Record, 43, 243-270.

Grisante, P. C., de Rose, J. C., \& McIlvane, W. J. (2014). Controlling relations in stimulus equivalence classes of preschool children and individuals with Down Syndrome. The Psychological Record, 64(2), 195-208. doi:10.1007/s40732-014-0021-3 
Guinther, P. M., \& Dougher, M. J. (2010). Semantic false memories in the form of derived relational intrusions following training. Journal of the Experimental Analysis of Behavior, 93, 329-347. doi:10.1901/jeab.2010.93-329

Halford, J. C. G., Boyland, E. J., Hughes, G, Oliveira, L. P., \& Dovey, T. M. (2007). Beyond-brand effect of television (TV) food advertisements/ commercials on caloric intake and food choice of 5-7-year-old children. Appetite, 49, 263-267.

Halford, J. C. G., Gillespie, J., Brown, V., Pontin, E. E., \& Dovey, T. M. (2004). Effect of television advertisements for foods on food consumption in children. Appetite, 42, 221-225.

Kotler, J. A., Schiffman, J. M., \& Hanson, K. G. (2012). The Influence of media characters on children's food choices. Journal of Health Communication, 17(8), 886-898. doi:10.1080/10810 730.2011 .650822

Kraak, V. I., \& Story, M. (2015). Influence of food companies' brand mascots and entertainment companies' cartoon media characters on children's diet and health: A systematic review and research needs. Obesity Reviews, 16, 107-126. doi:10.1111/obr.12237

Lapierre, M. A., Vaala, S. E., \& Linebarger, D. L. (2011). Influence of licensed spokes characters and health cues on children's ratings of cereal taste. Archives of Pediatrics \& Adolescent Medicine, 165(3), 229-234.

Macklin, N. C. (1986). Classical conditioning effects in product/character pairings presented to children. Advances in Consumer Research, 13, 198-203.

Mehta, K., Phillips, S., Ward, P., Coveney, C., Hnadsley, E., \& Carter, P. (2012). Marketing foods to children through product packaging: Prolific, unhealthy and misleading. Public Health Nutrition, 15(9), 1763-1770. doi:10.1017/ S1368980012001231

Mizael, T. M., de Almeida, J. H., Silveira, C. C., \& de Rose, J. C. (2016). Changing racial bias by transfer of functions in equivalence classes. The Psychological Record, 66, 451-462. doi:10.1007/ s40732-016-0185-0

Mizael, T. M., Santos, S. L., \& de Rose, J. C. (2016). Contribuições do paradigma de equivalência de estímulos para o estudo das atitudes [Contributions of stimulus equivalence paradigm for studying attitudes]. Interação em Psicologia,
20(2), 124-134. doi:http://dx.doi.org/10.5380/ psi.v20i2.46278

Moxon, P., Keenan, M., \& Hine, L. (1993). Genderrole stereotyping and stimulus equivalence. The Psychological Record, 43, 381-394.

Osgood, C. E., Suci, G. I., \& Tannenbaum, P. H. (1957). The measurement of meaning. Urbana, IL: University of Illinois Press

Roberto, C. A., Baik, J., Harris, J. L., \& Brownell, K. D. (2010). Influence of Licensed characters on Children's Taste and Snack Preferences. Pediatrics, 26, 88-93.

Robinson, T. N., Borzekowski, D. L. G., Matheson, D. M., \& Kraemer, H. C. (2007). Effects of fast food branding on young children's taste preferences. Archives of Pediatrics \& Adolescent Medicine, 161(8), 792-797.

Sidman, M. (1994). Equivalence relations and behavior. A research story. Boston, MA: Authors Cooperative.

Sidman, M., \& Tailby, W. (1982). Conditional discrimination vs. matching to sample: An expansion of the testing paradigm. Journal of the Experimental Analysis of Behavior, 37(1), 5-22. doi:10.1901/jeab.1982.37-5

Silveira, J. H., Aggio, N. M., Cortez, M. D., Bortoloti, R., Rico, V. V., \& de Rose, J. C. (2015). Maintenance of equivalence classes and transfer of functions: The role of the nature of stimuli. The Psychological Record, 66, 65-74. doi:10.1007/ s40732-015-0152-1

Smeets, P. M., \& Barnes-Holmes, D. (2003). Children's emergent preferences for soft drinks: Stimulus-equivalence and transfer. Journal of Economic Psychology, 24, 603-618.

Straatmann, G., Almeida, S. S., \& de Rose, J. C. (2014). Computerized assessment of food preferences in adolescents in the stimulus equivalence paradigm. Trends in Psychology, 22(3), 613-624. doi:10.9788/TP2014.3-07

Stuart, E. W., Shimp, T. A., \& Engle, R. W. (1987). Classical conditioning of consumer attitudes: Four experiments in an advertising context. Journal of Consumer Research, 14, 334-349.

Sweldens, S., Van Osselaer, S. M. J., \& Janiszewski, C. (2010). Evaluative conditioning procedures and the resilience of conditioned brand attitudes. Journal of Consumer Research, 37(3), 473-489. doi:http://dx.doi.org/10.1086/653656 
Valenti, S. S. (1985). Children's preference for novelty in selective learning: Developmental stability or change? Journal of the Experimental Child Psychology, 40, 406-419.

Valkenburg, P. M., \& Buijzen, M. (2005). Identifying determinants of young children's brand awareness: Television, parents, and peers. Applied Developmental Psychology, 26, 456-468.

Watt, A., Keenan, M., Barnes, D., \& Cairns, E. (1991). Social categorization and stimulus equivalence. The Psychological Record, 41, 33-50.

World Health Organization. (2015). Childhood overweight and obesity. Retrieved from http://www. who.int/dietphysicalactivity/childhood/en/
Wulfert, E., \& Hayes, S. C. (1988). Transfer of a conditional ordering response through conditional equivalence classes. Journal of the Experimental Analysis of Behavior, 50, 125-144.doi:10.1901/ jeab.1988.50-125

(C) The Author(s), 2018. Open Access. This article is distributed under the terms of the Creative Commons Attribution 4.0 International License (http://creativecommons.org/licenses/by/4.0/), which permits unrestricted use, distribution, and reproduction in any medium, provided you give appropriate credit to the original author(s) and the source, provide a link to the Creative Commons license, and indicate if changes were made. 